\author{
М.О.ЛІаріонов \\ аспірант кафедри фінансового права та фіскального адміністрування \\ Національної академії внутрішніх справ
}

\title{
ОСОБЛИВОСТІ МОНІТОРИНГУ КОНТРОЛЬОВАНИХ ОПЕРАЦІЙ В УКРАЇНІ: ШІЛЯХИ ВДОСКОНАЛЕННЯ
}

Законодавство з фінансово-правового регулювання трансфертного ціноутворення діє в Україні порівняно недовго - з вересня 2013 року. Лише нещодавно фіскальні органи почали активно здійснювати податковий контроль за трансфертним ціноутворенням, важливим складником якого є моніторинг контрольованих операцій.

Питанням фінансово-правового регулювання трансфертного ціноутворення приділяли увагу такі вітчизняні та зарубіжні вчені, як: Н.Х. Вафіна, А.В. Гарбінська-Руденко, Р.В. Джоха, Д. де Кароліз, М. Маркхема, М.О. Мішин, К.А. Непесов, П.А. Селезень, Л.В. Товкун, Дж. Озборн тощо. Водночас особливості моніторингу контрольованих операцій наразі не знайшли належного аналізу у вітчизняній науці.

Мета статті - проаналізувати процедуру та особливості моніторингу контрольованих операцій в Україні, виокремити основні етапи процедури моніторингу контрольованих операцій в Україні та запропонувати шляхи вдосконалення крізь призму міжнародного досвіду.

Моніторинг - це специфічна форма податкового контролю у сфері трансфертного ціноутворення. Шляхом проведення моніторингу контролюючий орган аналізує, чи відповідають умови контрольованих операцій принципу «витягнутої руки», виявляє й аналізує потенційні ризики, пов'язані зі заниженням платником податків податкових зобов' язань, а також контролює своєчасність подання звіту про контрольовані операції та документації з трансфертного ціноутворення.

У процесі моніторингу контролюючий орган не здійснює особливого втручання в поточну діяльність платника податків, оскільки в більшості своїй аналізує інформацію, що вже наявна в розпорядженні контролюючого органу. Проте не варто недооцінювати значення моніторингу, оскільки в процесі його проведення у контролюючого органу може виникнути низка підстав для проведення позапланової документальної перевірки з питань дотримання принципу «витягнутої руки» .

Порядок проведення моніторингу визначається пп. 39.5.1. П. 39.5. ст. 39 Податкового кодексу України, Порядком проведення моніторингу контрольованих операцій, а також Порядком опитування уповноважених, посадових осіб та/ або працівників платника податків 3 питань трансфертного ціноутворення, затвердженими

\section{Постановою Кабінету Міністрів України від} 14.08.2015 року № 706 .

Податковий кодекс України не передбачає конкретних підстав для проведення моніторингу контрольованих операцій. Також контролюючий орган не зобов'язаний повідомляти платника податків про проведення такого моніторингу. Моніторинг здійснюється шляхом постійного та регулярного аналізу: 1) звітів про контрольовані операції та документації з трансфертного ціноутворення, поданих платником податків; 2) податкової інформації, отриманої контролюючим органам у порядку, передбаченому ст. 73 Податкового кодексу України; 3) інших інформаційних джерел. Такими джерелами є дані контролюючих та інших державних органів України та інших держав, а також будь-які інші джерела, де міститься відкрита інформація про зіставні операції та осіб або можливі ризики заниження податкових зобов'язань (наприклад, податкова та фінансова звітність, бази даних Ruslana, Amadeus, біржові котирування товару, форвардні або ф’ючерсні біржові котирування товару тощо).

Крім того, на етапі аналізу звітів про контрольовані операції та документації з трансфертного ціноутворення контролюючий орган має право проводити опитування уповноважених осіб і співробітників платника податків. Контролюючий орган на власний розсуд визначає необхідність проведення опитування, етапи такого опитування, а також обсяг запитань, що ставляться. Контролюючий орган може опитувати осіб, які були відповідальні за прийняття рішень щодо контрольованих операцій, готували або підписували відповідні документи (контракти, фінансову, технічну та іншу документацію), готували звіт про контрольовані операції або документацію 3 трансфертного ціноутворення. Контролюючий орган надсилає повідомлення про проведення опитування не менше ніж за 7 календарних днів або вручає його не менше ніж за 2 робочі дні до дати проведення опитування. Місце проведення опитування - приміщення контролюючого органу. Якщо хтось з опитуваних осіб не може з'явитися для опитування у передбачений час, платник податку має письмово повідомити про це контролюючий орган не менше ніж за один робочий день до дня проведення опитування, зазначити причини неявки, а також запропонувати для узгодження 
інший час. Результати опитування оформлюються протоколом, один з екземплярів якого вручається опитуваній особі. У разі відмови опитуваної особи підписати або отримати свій примірник акта контролюючий орган складає акт, який посвідчує факт відмови [2].

Процедура моніторингу контрольованих операцій в Україні в цілому відповідає рекомендаціям ООН та ОЕСР, але має й певні особливості. Так, відповідно до п. С. 3.3.6.2. Практичного керівництва ООН з трансфертного ціноутворення для країн, що розвиваються, контролюючий орган має обирати платників податків, щодо яких проводитиметься перевірка, застосовуючи процедуру ідентифікації та оцінювання ризиків. Саме ця процедура є тотожною моніторингу контрольованих операцій. Оцінювання ризиків рекомендується здійснювати за такою процедурою: 1) первинне дослідження та ідентифікація потенційних ризиків; 2) класифікація потенційних ризиків; 3) збір додаткових відомостей; 4) прийняття рішення про продовження дослідження; 5) глибокий аналіз ризиків, що включає в себе аналіз документації з трансфертного ціноутворення та проведення функціонального аналізу з метою підтвердження результатів первинного дослідження; 6) детальна кількісна оцінка потенційних ризиків; 7) первинна взаємодія з платником податків; 8) прийняття рішення про проведення перевірки [3].

Відповідно до п. С. 3.3.2.3. Практичного керівництва ООН рекомендовано затвердити класифікацію ризиків у сфері трансферного ціноутворення. Як приклад наведено таку класифікацію: 1) умисне виведення прибутку з-під оподаткування через нові структурні утворення; 2) умисне виведення прибутку з-під оподаткування через реструктуризацію; 3) умисне виведення прибутку з-під оподаткування через неправильний функціональний аналіз, використання неправильних методів трансфертного ціноутворення та інші зловживання нормами, що регулюють трансфертне ціноутворення; 4) тонка капіталізація (визнання процентів, нарахованих за борговими операціями 3 пов'язаними особами-нерезидентами, витратами) [3].

OECP розроблено детальніший перелік індикаторів потенційних ризиків, пов'язаних з трансфертним ціноутворенням, які можуть бути виявлені шляхом міждержавного обміну інформацією відповідно до Кроку 13 Плану BEPS: 1) фінансовий результат платника податків відрізняється від результатів зіставних юридичних осіб; 2) фінансовий результат не відображає тенденцій ринку; 3) юридична особа-нерезидент, яка не виконує значних функцій, не використовує значні активи та не несе значних ризиків, має значні прибутки; 4) юридична особа-нерезидент має значні прибутки, які оподатковуються за низькою податковою ставкою; 5) юридична особа-нерезидент виконує значні функції, використовує значні активи та несе значні ризики, але несе невеликі прибутки (несе невеликі збитки); 6) група здійснює діяльність в офшорних юрисдикціях; 7) здійснювалася реструктуризація, зокрема, переміщення активів; 8) об’єкти інтелектуальної власності відокремлені від відповідної діяльності в межах групи; 9) до складу групи входять маркетингові компанії, розташовані за межами ключових ринків збуту; 10) до складу групи входять закупівельні компанії, розташовані поза ключовими виробничими локаціями; 11) обсяг податку на прибуток підприємств (корпоративного податку), що фактично сплачується до бюджету, на постійній основі менший за обсяг нараховуваного податку; 12) до складу групи входять компанії, які мають подвійне резидентство; 13) до складу групи входять компанії, що не є резидентами жодної з держав; 14) група розкриває доходи, які не оподатковуються в жодній юрисдикції; 15) інформація, отримана в результаті міждержавного обміну, не відповідає відомостям, що були попередньо надані платником податків [4].

ОЕСР розроблено рекомендації щодо здійснення ефективної оцінки податкових ризиків: 1) оцінка ризиків має здійснюватися об'єктивно, наприклад, шляхом застосування спеціально розроблених алгоритмів та інших інструментів; 2) службові особи контролюючого органу, які залучаються до оцінювання ризиків, мусять мати достатній рівень підготовки та досвід у ключових сферах, що використовуються під час оцінювання ризиків (податкове право, трансфертне ціноутворення, ризик-менеджмент, бухгалтерський облік, економіка, статистика тощо); 3) оцінювання ризиків має використовуватися для вибору платників податків, які підлягатимуть подальшому контролю шляхом проведення податкової перевірки, а не як додатковий етап перевірки; 4) процедура оцінювання ризиків має бути динамічною та періодично переглядатися; 5) стратегія оцінювання ризиків має поєднувати різні інструменти та враховувати різні фактори, що можуть вплинути на показник ризикованості [4].

Як зазначено вище, в Україні процедура моніторингу є схожою та в цілому відповідає міжнародним стандартам, проте має свої особливості. Так, можна виділити три етапи в процедурі моніторингу контрольованих операцій.

І етап - первинний аналіз інформації. На цьому етапі контролюючий орган аналізує інформацію, яка міститься в податковій, фінансовій звітності, митних деклараціях платника податків, а також інформацію про ціни та умови контрольованих операцій і аналогічну інформацію про зіставні неконтрольовані операції.

Цей етап є базовим, оскільки з урахуванням його результатів відбувається подальший аналіз 
звітів про контрольовані операції та документації з трансфертного ціноутворення, а також приймається рішення про проведення перевірки.

Аналіз звітів про контрольовані операції здійснюється, зокрема, шляхом співставлення даних податкової звітності платника податків. До уваги беруться, зокрема, такі відомості: 1) з митних декларацій - щодо обсягів експортно-імпортних операцій з окремими нерезидентами; 2) з податкових декларацій з податку на прибуток - щодо збільшення фінансового результату звітного періоду на суму 30 відсотків вартості товарів, придбаних у нерезидентів, зареєстрованих у державах, зазначених у пп. 39.2.1.2 п. 39.2 ст. 39 Податкового кодексу України; на суму перевищення нарахованих процентів, що виникли за операціями з пов'язаними особами - нерезидентами (рядки 3.1.7 та 3.1.1 додатка PI до рядка 03 PI податкової декларації); 3) з єдиного реєстру податкових накладних - щодо операцій з постачання послуг нерезидентами на митній території України; 4) зі звіту про фінансовий результат - щодо фінансових витрат (рядок 2250) [5].

Контролюючий орган має право звернутися з письмовим запитом про надання додаткової інформації, якщо проведений аналіз свідчить про наявність ризиків невідповідності контрольованих операцій принципу «витягнутої руки» або заниження податкових зобов'язань [2]. Такий запит подається в порядку, передбаченому п. 73.3 ст. 73 Податкового кодексу України, - у запиті вказуються підстави його направлення, інформація, яка підтверджує наявність цих підстав, а також перелік інформації та документів, які має надати платник податків. Запит завіряється підписом керівника контролюючого органу (або іншою уповноваженою особою) і печаткою. Якщо ці вимоги не виконуються, платник податків звільняється від обов'язку надати запитувану інформацію. Якщо ж запит контролюючого органу відповідає всім викладеним вище вимогам, запитувану інформацію необхідно надати протягом 15 робочих днів $з$ дня отримання запиту.

Якщо під час первинного аналізу інформації платник податків виявив самостійно або контролюючий орган повідомив про невідповідність контрольованих операцій принципу «витягнутої руки», платник податків має право провести самостійне коригування ціни і сум податкових зобов'язань (за умови, що внаслідок таких дій не буде зменшена сума податкових зобов'язань).

Під час самостійного коригування платник податків може на власний розсуд обрати показник коригування (максимальне чи мінімальне значення діапазону цін або рентабельності). Контролюючий орган коригує ціни і суми податкових зобов'язань до рівня медіани діапазону цін (рентабельності), що може призвести до значного збільшення податкових зобов'язань платника. Діапазон та медіана цін (рентабельності) розраховується відповідно до Порядку розрахунку діапазону цін (рентабельності) та медіани такого діапазону для цілей трансфертного ціноутворення, затвердженого Постановою Кабінету Міністрів України від 04.06.2015 року № 381 .

Суму податкових зобов'язань, визначену шляхом самостійного коригування, необхідно сплатити протягом 10 календарних днів з дня проведення такого коригування. У разі несвоєчасної сплати нарахування пені розпочинається після спливу 270 календарних днів, наступних за останнім днем граничного строку сплати податкового зобов'язання.

Враховуючи, що платник податків втрачає право на самостійне коригування під час проведення перевірки з питань дотримання принципу «витягнутої руки», потрібно оцінити можливі розміри донарахувань під час проведення самостійного коригування та коригування контролюючим органом уже на етапі отримання запиту про надання додаткової інформації. Якщо донарахування в результаті самостійного коригування є незначними, доцільним видається здійснити таке коригування, не чекаючи початку податкової перевірки.

II етап - аналіз звітів про контрольовані операції. Основним завданням цього етапу є контроль за своєчасністю подачі звітів про контрольовані операції, а також повнотою вказаних у них відомостей.

Під час проведення аналізу звітів про контрольовані операції контролюючий орган використовує джерела, які містять інформацію про господарську діяльність платника податків, про зіставні операції і осіб, а також результати первинного аналізу інформації. Окрема увага приділяється фінансово-господарським показникам, які можуть свідчити про невідповідність контрольованих операцій принципу «витягнутої руки». Наприклад, OECP у п. 1.35. параграфа D.1 розділу I Настанов щодо трансфертного ціноутворення для транснаціональних компаній та податкових служб (у ред. 2010 року) зазначає, що невідповідність фінансового результату середнім показникам по галузі може свідчити про те, що прибуток, який платник податків отримує в результаті співпраці з пов'язаними особами, не відповідає прибутку, який він міг отримати в результаті співпраці з незалежними компаніями (за умови проведення необхідних коригувань для зіставності показників) [6].

Інший приклад - збитковість протягом декількох звітних періодів поспіль. За таких умов незалежна компанія, яка не входить до складу групи компаній, припинить діяльність, тоді як компанія, діяльність якої більшою мірою спрямована на задоволення потреб групи, продовжує роботу для забезпечення загального прибутку групи. 
Така ситуація може розцінюватися контролюючим органом як підтвердження невідповідності принципу «витягнутої руки», оскільки збиткова компанія нібито не отримує належної компенсації за свої товари (роботи, послуги) [6].

Якщо аналіз звітів про контрольовані операції свідчить про невідповідність принципу «витягнутої руки», ДФС за запитом контролюючого органу або самостійно може прийняти рішення про направлення платникові податків запиту про надання документації з трансфертного ціноутворення. Такий запит може направлятися не раніше 1 жовтня року, наступного за календарним роком, коли була здійснена контрольована операція.

Платник зобов'язаний надати документацію в орган, зазначений у запиті, протягом 30 календарних днів з дня отримання запиту. Оскільки ПК України містить досить широкий перелік інформації, що має включатися до документації з трансфертного ціноутворення, доцільно підготувати іï заздалегідь, а після отримання запиту лише за необхідності оновити їі.

III етап - аналіз документації з трансфертного ціноутворення. На цьому етапі контролюючий орган перевіряє повноту розкриття інформації в документації відповідно до вимог пп. 39.4.6. п. 39.4. ст. 39 Податкового кодексу України.

Документація з трансфертного ціноутворення обов'язково має містити такі дані: 1) відомості про юридичну особу - сторону контрольованої операції і асоційованих осіб (у звітному році і на момент подачі документації); 2) загальний опис діяльності групи компаній; 3) опис структури управління платника податків, схема його організаційної структури; 4) опис діяльності та стратегії ділової активності платника податків; 5) відомості про участь у реструктуризації або передачі нематеріальних активів у звітному або попередньому році; 6) опис контрольованої операції (необхідно додати копії договорів); 7) опис товарів (робіт, послуг); 8) дані про фактично здійснені розрахунки в контрольованих операціях; 9) фактори, які вплинули на формування ціни; 10) функціональний аналіз контрольованої операції; 11) економічний і порівняльний аналіз з неконтрольованими зіставними операціями; 12) відомості про здійснене самостійне пропорційне коригування [1].

Якщо в документації наявна неповна інформація 3 питань, викладених вище, контролюючий орган направляє запит з вимогою про надання інформації, якої бракує. Строк надання запитуваної інформації - 30 календарних днів з дня отримання запиту. Ненадання документації у передбачений строк є підставою для проведення перевірки.

Крім повноти розкриття інформації, контролюючий орган також досліджує достатність і повноту обгрунтування відповідності умов контрольованих операцій принципу «витягнутої руки».
Результати аналізу документації, які свідчать про невідповідність умов контрольованих операцій принципу «витягнутої руки», використовуються під час прийняття рішення про проведення перевірки як підтвердження наявності підстав для її проведення.

Таким чином, моніторинг є первинною ланкою в процедурі податкового контролю за відповідністю умов контрольованих операцій принципу «витягнутої руки». Відомості, отримані в результаті моніторингу, використовуються під час прийняття рішення про проведення перевірки, а також як додаткова інформація безпосередньо в процесі проведення перевірки.

Порівнюючи процедуру моніторингу контрольованих операцій в Україні зі стандартами ООН та OECP, можна виділити деякі аспекти, які, на нашу думку, потребують покращення.

Так, відповідно до міжнародних рекомендацій контролюючий орган уперше контактує з платником податків незадовго до прийняття рішення про проведення перевірки, закінчивши самостійний аналіз інформації, доступ до якої контролюючий орган може отримати самостійно. В Україні ж контролюючий орган, крім подання запиту на отримання документації з трансфертного ціноутворення на третьому етапі моніторингу, має право подавати запити на отримання додаткової інформації в порядку, передбаченому ст. 73 ПК України, на етапах первинного аналізу інформації, аналізу звітів та після аналізу документації, що має наслідком витрачання додаткових ресурсів як з боку платника податків, так і з боку контролюючого органу. Доцільним видається обмежити кількість контактів між контролюючим органом та платником податків лише двома запитами - запитом на надання документації з трансфертного ціноутворення та запитом на надання додаткової інформації, якщо в результаті аналізу документації з трансфертного ціноутворення не вдалося встановити всі необхідні дані.

Також, на відміну від рекомендацій ОЕСР, порядок проведення моніторингу в Україні не передбачає обов'язку контролюючого органу підготувати фінальний звіт за результатами проведеного дослідження. Результати моніторингу частково відображаються в інформаційному повідомленні, що надсилається як обгрунтування доцільності проведення перевірки, проте платник податків не має можливості з ним ознайомитись. Формування підсумкового звіту за результатами моніторингу, примірник якого надсилався б платникові податків для ознайомлення (за аналогією з актом або довідкою про проведення перевірки), має низку позитивних наслідків. По-перше, платник податків розумітиме, в якому напрямі здійснюватиметься податкова перевірка, по-друге, матиме можливість, виходячи з інформації, викладеної в звіті, оскаржити наказ 
про проведення перевірки як безпідставний, та по-третє, в результаті ознайомлення зі звітом платник податків розумітиме, які саме операції здаються контролюючому органу ризиковими.

Ще однією відмінністю є відсутність законодавчо закріплених критеріїв ризиковості, які мають аналізуватися під час проведення моніторингу. Виокремлення таких критеріїв є важливим для підвищення об'єктивності здійснюваного контролюючим органом дослідження. Прикладом для України може стати досвід Канади, де запроваджена Інтегрована система оцінки ризиків, яка в автоматизованому режимі поєднує інформацію з баз даних контролюючого органу та різноманітних форм звітності, що подається до контролюючого органу. Після цього узагальнена інформація аналізується з використанням алгоритмів (близько 200), за допомогою яких оцінюється ризикованість кожного платника податків. Платники податків, визначені як такі, що мають середній або високий рівень ризику, надалі аналізуються повторно із залученням працівників контролюючого органу та додаткової інформації. Результатом такого аналізу є формування переліку платників податків, що підлягатимуть перевірці. Запровадження такого механізму в Україні зменшить рівень суб'єктивності результатів моніторингу, а також розвантажить податкові органи.

Зрозуміло, що введення в дію алгоритмів та автоматизованої системи є довготривалим процесом, проте формалізація критеріїв ризикованості може бути здійснена навіть шляхом видання листа ДФС з відповідними роз'ясненнями. Попри рекомендаційний характер таких листів, вони сприятимуть реалізації принципу правової визначеності для платника податків, оскільки контролюючий орган, як правило, дотримується позицій, викладених у листах ДФС. Платник податків матиме можливість передбачити наслідки вчинюваних ним контрольованих операцій для подальшого податкового контролю та, можливо, через це відмовитися від здійснення окремих операцій.

Запровадження вказаних змін, на нашу думку, не позбавить контролюючі органи інструментів для здійснення дієвого контролю за відповідністю контрольованих операцій принципу «витягнутої руки», проте убезпечить платників податків від тиску з боку контролюючих органів.

\section{Jimepamypa}

1. Податковий кодекс України від 02.12.2010 № 2755-VI. URL: http://zakon2.rada.gov.ua/laws/ show/2755-17/print1329730624868809.

2. Про затвердження Порядку проведення моніторингу контрольованих операцій та Порядку опитування уповноважених, посадових осіб та/або працівників платника податків 3 питань трансфертного ціноутворення : Наказ Міністерства фінансів України від 14.08.2015 року № 706. URL: https://zakon.rada.gov.ua/ laws/show/z1055-15.
3. Практичне керівництво ООН з трансфертного ціноутворення для країн, що розвиваються. URL: https:// www.un.org/esa/ffd/wp-content/uploads/2017/04/ Manual-TP-2017.pdf.

4. Country-by-Country Reporting : Handbook on Effective Tax Risk Assessment, OECD. URL: http://www.oecd.org/tax/beps/country-by-countryreporting-handbook-on-effective-tax-risk-assessment.pdf.

5. Щодо кампанії звітування про контрольовані операції. Лист ДФС України від 18.08.2017 року № 22283/7/99-99-12-03-07-17. URL: https:// zakon.rada.gov.ua/rada/show/v2283872-17/print.

6. Настанови ОЕСР щодо трансфертного ціноутворення для транснаціональних компаній та податкових служб (у ред. 2010 року). URL: http://www.afo.com.ua/ doc/Nastanovy_OESR.pdf.

\section{Анотація}

Ларіонов М. О. Особливості моніторингу контрольованих операцій в Україні: шляхи вдосконалення. Стаття.

У статті проаналізовано процедуру та особливості фінансово-правового регулювання моніторингу контрольованих операцій в Україні. Виділено основні етапи процедури моніторингу контрольованих операцій в Україні: 1) первинний аналіз інформації; 2) аналіз звітів про контрольовані операції; 3) аналіз документації з трансфертного ціноутворення та проаналізовано ïх особливості. Констатовано, що моніторинг є первинною ланкою в процедурі податкового контролю за відповідністю умов контрольованих операцій принципу «витягнутої руки», а відомості, отримані в результаті моніторингу, використовуються під час прийняття рішення про проведення перевірки з питань дотримання принципу «витягнутої руки», а також як додаткова інформація безпосередньо в процесі проведення перевірки 3 питань дотримання принципу «витягнутої руки». Порівняно процедуру моніторингу контрольованих операцій в Україні з міжнародними стандартами $\mathrm{OOH}$ та ОЕСР та виділено основні відмінності: 1) значна кількість контактів між контролюючим органом та платником податків в Україні; 2) порядок проведення моніторингу контрольованих операцій в Україні не передбачає обов'язку контролюючого органу підготувати фінальний звіт за результатами проведеного дослідження; 3) відсутність в Україні нормативно закріплених критеріїв ризиковості, які мають аналізуватися під час проведення моніторингу контрольованих операцій. Запропоновано шляхи вдосконалення процедури моніторингу контрольованих операцій в Україні з урахуванням міжнародних стандартів.

Ключові слова: документація з трансфертного ціноутворення, контрольована операція, моніторинг, моніторинг контрольованих операцій, принцип «витягнутої руки», податковий контроль, ОЕСР, ООН, трансферне ціноутворення.

\section{Summary}

Larionov $M$. O. Peculiarities of monitoring of controlled operations in Ukraine: ways to improve. Article.

The article analyzes the procedure and peculiarities of financial and legal regulation of the monitoring of controlled operations in Ukraine. The main stages of the monitoring procedure of controlled operations in Ukraine are highlighted, namely: 1) primary analysis of information; 2 ) analysis of reports on controlled operations; 3) analysis of transfer pricing documentation and analyzed their features. It is stated that monitoring is the primary stage in 
the tax control procedure for compliance of the conditions of controlled operations with the "arm's length" principle, and information obtained as a result of monitoring is used when deciding whether to conduct an audit for compliance with the arm's length principle as well as additional information directly in the process of conducting an audit on compliance with the "arm's length" principle. Comparison of monitoring procedures of controlled operations in Ukraine with international standards of the UN and the OECD was carried out and the main differences were highlighted: 1) a significant number of contacts between the controlling authority and the taxpayer in Ukraine; 2) the procedure for monitoring the controlled operations in Ukraine does not provide for the obligation of the supervisory authority to prepare the final report on the results of the study; 3) the absence in Ukraine of regulatory fixed criteria of riskiness, which should be analyzed during the monitoring of controlled operations. The ways of improving the monitoring procedure of controlled operations in Ukraine based on international standards are proposed.

Key words: transfer pricing documentation, controlled operation, monitoring, monitoring of controlled operations, "arm's length» principle, tax control, UN, OECD, transfer pricing. 